Latvian Journal of Chemistry, No 4, 2012, 376-382

DOI: $10.2478 / \mathrm{v} 10161-012-0023-\mathrm{x}$

\title{
ADVANCED RESEARCH OF THE TRIASSIC CLAY FROM THE BALTIC REGION
}

\author{
J. Karasa, J. Kostjukovs, A. Palaša, A. Actiņš \\ Department of Chemistry, University of Latvia, \\ Krišjāṇa Valdemāra iela, 48, Riga, LV-1013, Latvia \\ E-mail: julija.karasa@lu.lv
}

A procedure of smectite containing clay enrichment has been optimized, and the process of sedimentation has been studied. The new enrichment based method for quantitative determination of clay fraction in smectite containing sediment was developed. A new method for obtaining organoclays from enriched smectite clays has been investigated. The method is based on solid-state reaction between smectite and organic compounds, where organic molecules can be intercalated in dried clay mineral (montmorillonite) by solid-state reactions, without or with use of solvents. The enriched clay and the obtained organoclay samples were characterized with X-ray powder diffraction (PXRD).

Key words: Triassic clays, montmorillonite, smectite, coagulation, organoclays

\section{INTRODUCTION}

Triassic clays of the Baltic region mainly consist of smectite type clay minerals. Smectites are an important class of clay minerals with several characteristic properties: high cation-exchange capacity, adsorption, high surface area, and swelling behavior [1].

The content of smectites in Baltic Triassic clay is relatively low - only 30 $40 \%$. Besides clay minerals, there are significant amounts of feldspar, quartz, and carbonates (sometimes up to 50\%). The procedure of activation and enrichment of these clays followed by the extraction of smectite concentrate increases the clay sorption capacity and reduces the amount of impurities. Extraction of smectite concentrate with a water soluble organic coagulant (KOHIDRAC) results in complete removal of carbonates, and quartz free smectite clays are obtained [2].

The proposed method is based on dispersing smectite containing clay in sodium phosphate solutions, resulting in phosphate stabilized clay suspensions [2]. Stability of smectite-phosphate suspensions was studied to evaluate sedimentation equilibrium for potential use of such smectite suspensions as liquid sorbents.

A new method for quantitative determination of clay fraction in smectite containing sediment samples is suggested. Sedimentation procedure is a method for increasing the clay fraction, but it does not provide the necessary amount of clay for detailed analysis, and is time-consuming. By using sodium phosphate solutions and water soluble coagulant it is possible to extract from sediments 
a clay fraction under $1 \mu \mathrm{m}$ for detailed analysis. The product did not contain carbonates, even if such minerals had been present in the sediments.

Smectite clays are mainly used for obtaining organocomplexes with different properties for various applications. Clay-organic derivatives have found application as rheological control agents, like lubricants, drilling fluids, greases, oils, paints, and even antibacterial materials and coatings [3, 4]. Moreover, organoclays have been applied to remove water pollutants such as organic compounds, pesticides and herbicides, anionic contaminants, heavy metals, and pharmaceutical products. Organocomplexes from smectites and ionic liquids potentially can be used as reagents or catalysts in organic synthesis [1,5].

A critical factor in chemical synthesis procedures is the use of organic solvents, as these are often harmful, flammable, and also expensive. For advanced investigations, smectite complexes with organic compounds can be obtained in an environmentally friendly manner, by solid-state interactions and without using organic solvents. Deionized water was used for this purpose as cation exchange medium [6]. A solid-state reaction between the Baltic region smectite clay and two common cationic surfactants (octadecyltrimethylammonium - ODTMA and hexadecyltrimethylammonium - HDTMA halides) resulted in organoclays - hydrophobic brown gels with crystalline structure. The same clay-organic derivatives usually have been obtained by ordinary timeconsuming cation exchange in aqueous solutions. Smectite organocomplexes with small organic molecules, such as ionic liquids, were also obtained by solidstate interaction.

\section{EXPERIMENTAL}

\section{Materials}

The Triassic smectite clay samples were obtained from a geological drill site $(10-12 \mathrm{~m})$ at the Vadakste deposit in Latvia and Saltiski deposit in Lithuania.

Sodium tripolyphosphate $\left(\mathrm{Na}_{5} \mathrm{P}_{3} \mathrm{O}_{10}\right.$, purchased from "Latvijas Ķimija”, $\geq 95 \%$ assay).

Acetone $\left(\mathrm{C}_{3} \mathrm{H}_{6} \mathrm{O}\right.$, purchased from SIA ,Enola”, $>99 \%$ assay).

Hydrazine dihydrochloride $\left(\mathrm{N}_{2} \mathrm{H}_{4} \cdot 2 \mathrm{HCl}\right.$, purchased from Sigma-Aldrich, $\geq 99 \%$ assay).

Methylene blue trihydrate $\left(\mathrm{C}_{16} \mathrm{H}_{18} \mathrm{ClN}_{3} \mathrm{~S} \cdot 3 \mathrm{H}_{2} \mathrm{O}\right.$, purchased from Fluka analytical, assay for dry substance $>95 \%$ ) was used for sorption experiments.

Octadecyltrimethylammonium chloride - ODTMA $\left(\mathrm{C}_{21} \mathrm{H}_{46} \mathrm{NCl}\right.$, purchased from Fluka Chemika, assay of surfactant $>98 \%$ ) and hexadecyltrimethylammonium bromide - HDTMA $\left(\mathrm{C}_{19} \mathrm{H}_{42} \mathrm{NBr}\right.$, purchased from Chemapol, Lachema, assay of surfactant $>94 \%$ ) were used for smectite clay organophilisation.

\section{Activation and enrichment of the smectite containing clay}

The activation and enrichment of clay from Vadakste and Saltiski deposits by dispersing in phosphate solutions, followed by extraction of smectite concentrate with the water soluble organic coagulant KOHIDRAC was carried out according to the techniques described in patent [2].

During the procedure of clay enrichment, calcium ions in smectite interlayer space were exchanged to sodium ions by adding dissolved sodium phosphates (activators) to clay suspensions. Sodium pyrophosphate $\left(\mathrm{Na}_{4} \mathrm{P}_{2} \mathrm{O}_{7} \cdot 10 \mathrm{H}_{2} \mathrm{O}\right)$ [7] 
and sodium tripolyphosphate $\left(\mathrm{Na}_{5} \mathrm{P}_{3} \mathrm{O}_{10}\right)$ [2] were the most effective activators used for smectite clay enrichment to stabilize clay suspensions.

Activated smectite-phosphate suspensions were left for $24 \mathrm{~h}$, and then decanted. According to the Stokes' law (Eq. 1), suspended particles (assumed as spherical) bigger than $1 \mu \mathrm{m}$ settled in $24 \mathrm{~h}$ (the preferred minimum time of sedimentation):

$$
v_{s}=\frac{2}{9} \cdot \frac{\left(\rho_{\rho}-\rho_{f}\right)}{\mu} g R^{2},
$$

where $v_{s}$ - the settling velocity of particles, $\mathrm{m} / \mathrm{s}$;

$g$ - local gravitational acceleration $\mathrm{m} / \mathrm{s}^{2}, g=9.8166 \mathrm{~m} / \mathrm{s}^{2}$ for Riga;

$\rho_{p}-$ density of the particles, $\mathrm{kg} / \mathrm{m}^{3}$;

$\rho_{f}$ - density of the fluid, $\mathrm{kg} / \mathrm{m}^{3}$;

$R$ - particle radius, $\mathrm{m}$;

$\mu-$ the viscosity of the dispersion medium, Pa.s.

For sodium smectite particle extraction after activation and decantation, KOHIDRAC coagulant was added to clay suspensions, and smectite particles aggregated as a result of that. KOHIDRAC is 4,5-dihydro-3,5,5-trimethylpyrazolium chloride, obtained as a product of acetone and hydrazine dihydrochloride condensation.

The extracted smectite aggregates were filtered and washed with water, airdried and crushed into a powder in agate mortar. The samples prepared as described above were used for solid-state organoclay synthesis.

\section{Organophilisation of enriched smectite}

The organophilisation procedure of clay was performed as described in the EU patent application [6] ("Mechanochemical method for obtaining organoclays from smectites"). The solid-state reaction between Latvian smectite clay and cationic surfactants (ODTMA and HDTMA) resulted in organoclays hydrophobic brown gels with crystalline structure.

\section{Method of analysis}

The X-ray powder diffraction (PXRD) analyses were performed for enriched clay and organoclay samples on a D8 Advance diffractometer (Bruker, 2005) with $0.6 \mathrm{~mm}$ divergence slits, $0.2 \mathrm{~mm}$ detector slit, $\mathrm{CuK} \alpha$ radiation $(0.15418 \mathrm{~nm})$. PXRD patterns were obtained for air-dried and crushed into powder enriched clay and organoclay samples in glass holders at a scanning speed of $1^{\circ} / \mathrm{s}$ in the $2 \Theta$ interval from 0.8 to $40^{\circ}$.

\section{Determination of clay sorption capacity}

The sorption capacity of the clay was determined with methylene blue dye [8]. The changes in adsorbate concentration after sorption were detected with a Lambda 25 UV/VIS spectrometer (Perkin Elmer) at $664.0 \mathrm{~nm}$.

\section{RESULTS AND DISCUSSION}

The process of clay enrichment, comparison of $P X R D$ results for raw and enriched clay

The coagulant was specific to sodium exchanged smectite, and acted similarly to hydrochloric acid by providing the necessary $\mathrm{pH}$ range for smectite 
particle aggregation and simultaneously dissolving carbonates, if present in the mineral. The intensities of quartz, calcite and dolomite reflections decreased, as shown by PXRD pattern of the enriched clay (Fig. 1). There were no reflections characteristic of sodium phosphate and KOHIDRAC in the PXRD pattern, because these compounds were washed out with water after extraction.

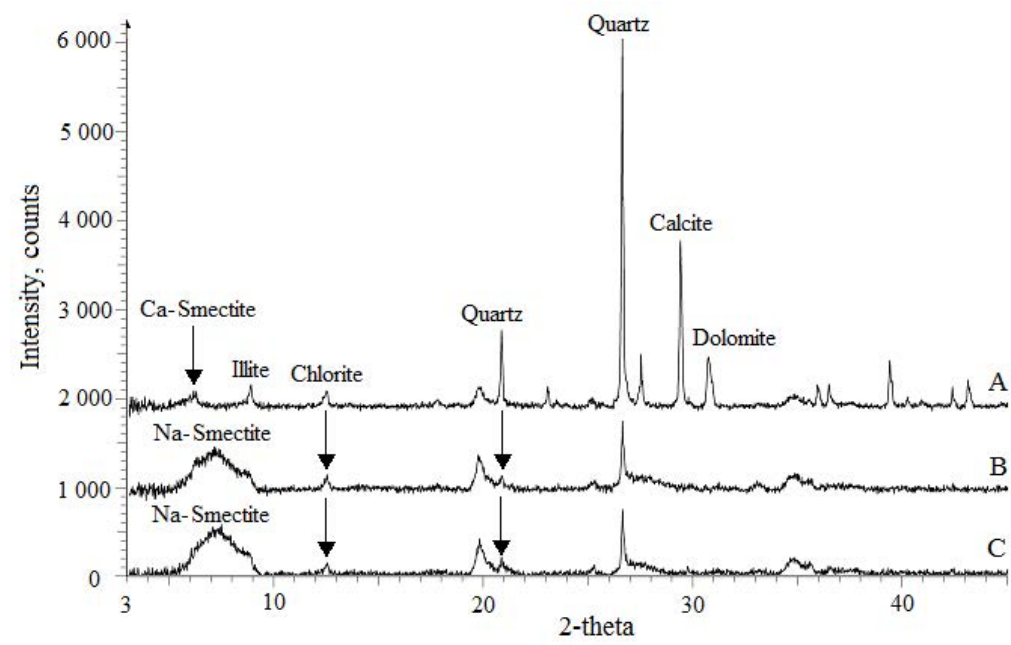

Fig. 1. PXRD patterns for the raw Vadakste deposit clay $(A)$, enriched Vadakste clay $(B)$ and clay from the Saltiski deposits $(C)$.

The quantity of quartz in the enriched clay (Fig. 2) after $24 \mathrm{~h}$ sedimentation had decreased from $\sim 20 \%$ to $3-4 \%$, and after 3 days down to $1-2 \%$. If clay suspensions were left for a longer time, to reach the equilibrium over 7-9 days, it was possible to obtain finer smectite fraction with quartz content $<1 \%$.

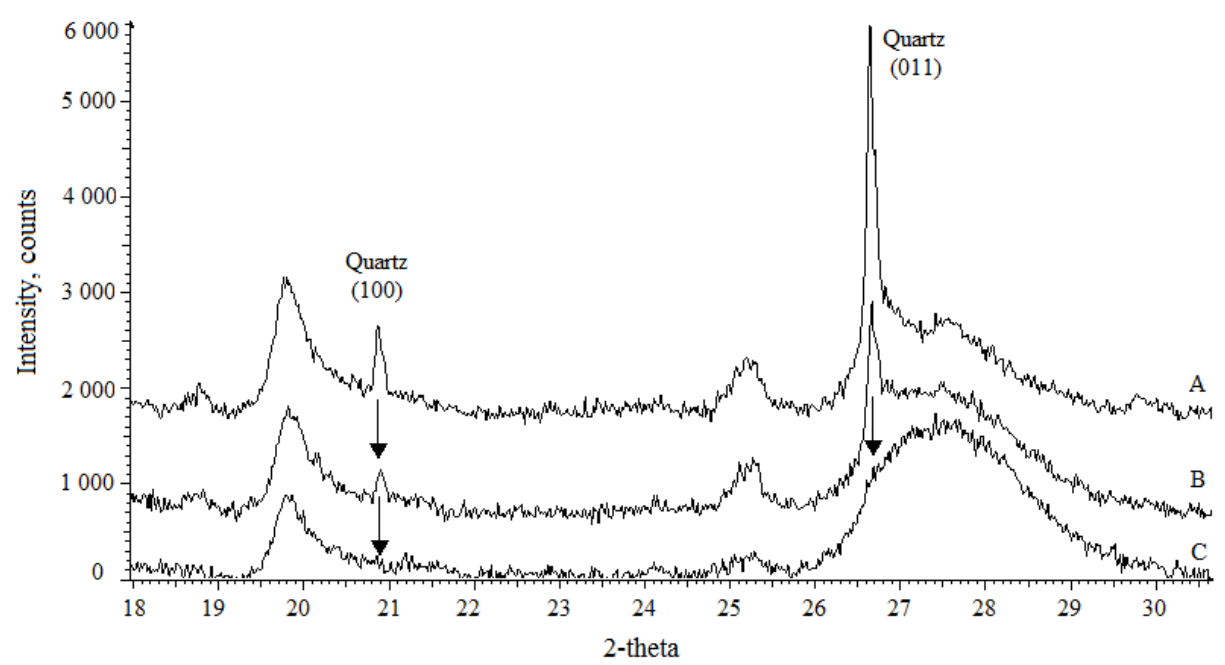

Fig. 2. PXRD patterns for quartz in enriched clay extracted for $24 \mathrm{~h}(A)$, for 3 days $(B)$, and for 7-9 days $(C)$.

Using the obtained data and equation (2), a theoretical curve for the sedimentation equilibrium was simulated (Fig. 3):

$$
W=W_{L}+\left(W_{0}-W_{L}\right) e^{-k t},
$$


where $W$ - mass fraction of the extracted smectite, \%;

$W_{L}$ - mass fraction of smectite extracted at sedimentation equilibrium, \%;

$W_{0}$ - the original mass fraction of smectite in suspension, $\%$;

$k$ - proportionality coefficient;

$t$ - time, days.

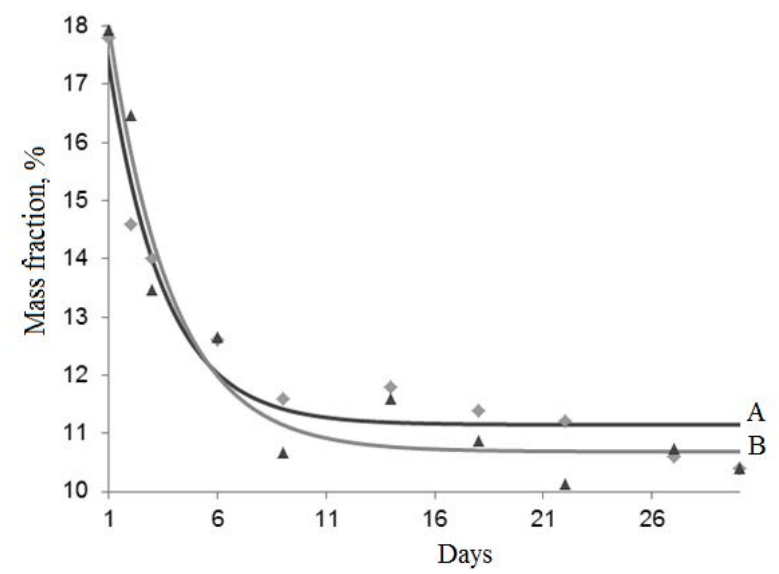

Fig. 3. The theoretical sedimentation equilibrium curves for smectite clay suspensions stabilized with $1,0 \mathrm{~g}$ sodium tripolyphosphate (clay sample mass $A-5 \mathrm{~g}, B-15 \mathrm{~g}$ )

The sedimentation equilibrium in tripolyphosphate stabilized smectite suspensions was reached in 7-9 days. Such clay-tripolyphosphate suspensions proved stable for at least one month.

Sorption properties

of enriched clays

The sorption capacity for two different samples of enriched clay was determined with the methylene blue method [8]. One sample of the enriched clay was extracted after $24 \mathrm{~h}$ of sedimentation, and the other sample was extracted after the sedimentation equilibrium had been reached (in 9 days). The sorption capacity of the enriched clay extracted after 9 days (for both Vadakste and Saltiski deposits) was found to be higher than that of clay extracted after $24 \mathrm{~h}$. The methylene blue sorption in clay increased from $0.50 \mathrm{mmol} / \mathrm{g}$ to $0.62 \mathrm{mmol} / \mathrm{g}$, as a result of finer smectite obtained during the steady state sedimentation.

Characterization of the obtained organoclay samples

by solid state reaction

The organophilisation of the enriched smectite clay was based on replacing the sodium ions in interlayer space of smectite to organic surfactant ammonium ions, and resulted in hydrophobic brown gels with crystalline structure. The obtained organoclay samples were characterized using X-ray powder diffraction (PXRD) method. The comparison of X-ray powder diffraction patterns for enriched Triassic clay from Vadakste deposit and mechanochemically obtained organoclay (Fig. 4.) indicated a shift of the characteristic sodium smectite reflection from $2 \theta=7.0^{\circ}$ to $2 \theta=2.2^{\circ}$ (ODTMA-smectite). The shift for HDTMA-smectite was to $2 \theta=2.5^{\circ}$. 


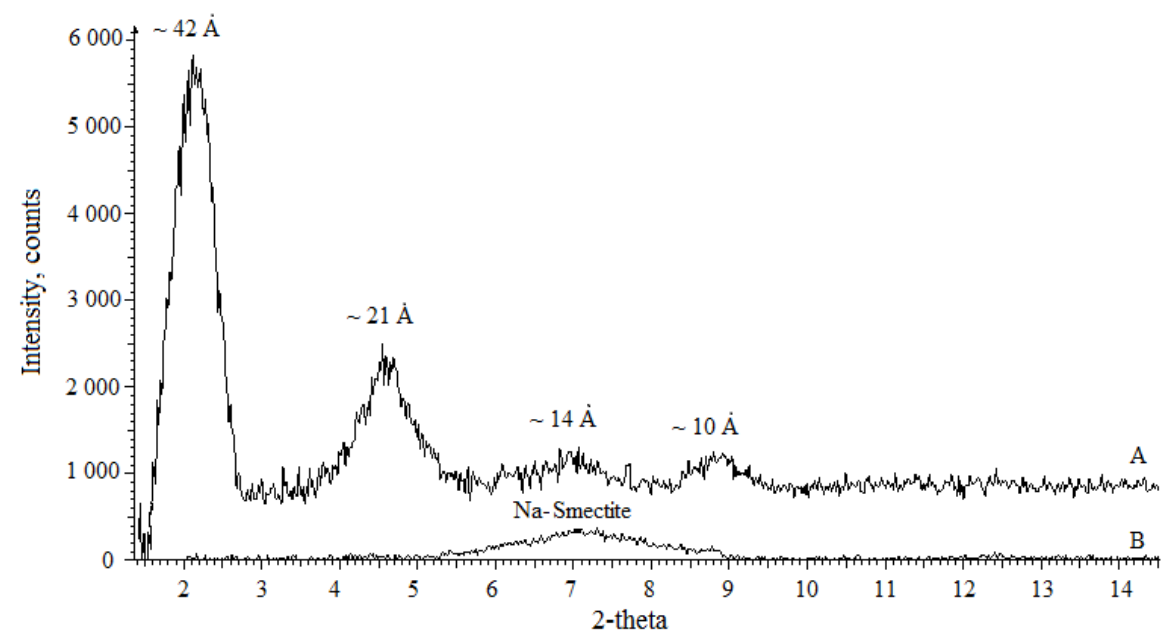

Fig. 4. PXRD patterns for enriched sodium smectite from Vadakste deposit $(B)$ and organoclay obtained by solid-state reaction with ODTMA $(A)$.

\section{CONCLUSIONS}

A new method for clay activation and enrichment has been developed. The method is fast and effective for smectite concentration, providing the necessary quantity of carbonate and quartz free smectite samples for advanced investigations. The content of smectite in one extraction cycle increased from $30-40 \%$ to $70 \%$, the remaining part of smectites was encapsulated in carbonates. Repeated extraction is not economically justified. The sorption capacity of enriched clay extracted after sedimentation equilibrium was reached (after 9 days of sedimentation) increased from $0.50 \mathrm{mmol} / \mathrm{g}$ to $0.62 \mathrm{mmol} / \mathrm{g}$. The new technique for obtaining organoclays from smectites and organic compounds by solid-state (mechanical) treatment without organic solvents was applied at one stage. The mechanochemical process for organoclay preparation significantly minimized the time and energy consumption, simultaneously providing high yields of the product.

\section{Acknowledgement}

The research was supported by ERDF funding under the agreement No. 2011/0014/2DP/2.1.1.1.0/10/APIA/VIAA/092.

\section{REFERENCES}

1. Betega de Paiva, L., Morales, A.R., Valenzuela Diaz, F.R. (2008). Organoclays: Properties, preparation and applications. Appl. Clay Sci., 42, 8-24.

2. Kostjukovs, J., Actinš, A., Sarceviča, I., Karasa, J. (15.12.2010) A method for extraction of smectites from low smectite content clays. EU patent Nr. EP 2465820 A1.

3. Yariv, S., Cross, H. (2002). Organo-Clay Complexes and Interactions. Marcel Dekker: Basel, New York.

4. Utracki, L.A. (2004). Clay-Containing Polymeric Nanocomposites. Vol. 1. Crewe: Rapra Technology.

5. Park, Y., Ayoko G.A., Frost R.L. (2011). Application of organoclays for the adsorption of recalcitrant organic molecules from aqueos media. J. Colloid Interface Sci., 354, 292-305.

6. Kostjukovs, J., Karasa, J., Actinš A. Mechanochemical method for obtaining organoclays from smectites. (EU patent application Nr. EP 1217 8295). 
7. Sarceviča, I., Kostjukovs, J., Actiňš, A. (2011). Enrichment and activation of smectite-poor clay. IOP Conf. Ser.: Mater. Sci. Eng., 23.

8. Sarceviča, I., Actiņš, A. (2009). Sorption analyses of smectite clay. Latv. J. Chem., 3, 187196.

\section{BALTIJAS REGIONA TRIASA MĀLU PERSPEKTĪVIE PĒTĪJUMI}

J. Karasa, J. Kostjukovs, A. Palaša, A. Actiņš

K O P S A V I L K U M S

Optimizēta smektītu mālu bagātināšanas metode un pētīts sedimentācijas process. Smektītu māla frakcijas kvantitatīvai atdalīšanai no smektītu saturošiem nogulumiem attīstīta jauna metode, kuras pamatā ir bagātināšanas process. Izstrādāta jauna metode organomālu iegūšanai no bagātinātiem smektītu māliem. Metodes pamatā ir cietfāžu reakcijas starp smektītiem un organiskajiem savienojumiem, kurās organiskās molekulas var tikt ievadītas mālu minerāla (montorilonīta) struktūrā ar vai bez šksīinātāja izmantošanas. Bagātinātu mālu un organomālu paraugi raksturoti ar pulvera rentgendifraktometrijas metodi. 